DRAFT - Open Concepts as crystallisation points and enablers of discursive configurations: the Case of the Innovation Campus in the Netherlands

Final version will be published in European Planning Studies as:

Kooij, H.J., Van Assche K.A.M. and Lagendijk A. (Forthcoming) Open concepts as crystallisation points and enablers of discursive configurations: The case of the innovation campus in the Netherlands, European Planning Studies. pp. 1-17. http://www.tandfonline.com/doi/full/10.1080/09654313.2012.731039 


\section{Open Concepts as crystallisation points and enablers of discursive configurations: the Case of the Innovation Campus in the Netherlands}

In this paper we reflect on the role of concepts in spatial planning as reproductive devices of discursive configurations. In contrast to instrumentalist interpretations of spatial concepts, we start from the idea that spatial planning concepts are inherently political. Building on post-structuralist strands of thought, we discuss the theoretical concepts of 'empty signifier' and 'master signifier' and instead, after analysis, put forward 'open concepts', in order to grasp the richness of meanings and functions of seemingly vague concepts. This manoeuvre allows us to analyse the trajectory and performance of the spatial concept of the 'innovation campus' in the Netherlands. This, in turn, opens the door to an analysis of planning concepts as crystallisation points and enablers of discursive configurations. The Dutch innovation campus is shown to be a result of a confluence of various national and international discourses, an open concept, flexible enough to enable the continuation of the planning game within the familiar set of coordinates. Because of the particular set of expectations associated with the innovation campus, promising structural change, it is bound to produce disappointment.

Keywords: spatial planning; planning concepts; spatial planning concepts; open concepts; innovation campus; empty signifier; master signifier; Lacan; Žižek 


\section{Introduction}

Spatial planning has a history of broad sweeping concepts playing a significant role in the shaping of ideas, plans and places. Planning can be seen as a site of production of and reflection on spatial concepts and their performance in planning practices. In this paper, we reflect on concepts in planning. More specifically, we investigate the role of concepts as products of confluences of discourses and as catalysts in the reproduction of discursive configurations. We will analyse how planning concepts can, under specific circumstances and in specific governance evolutions, function as enablers in the reproduction of discursive configurations tied to existing governance systems. We will demonstrate how this also applies to concepts that carry the promise of structural change. For that reason, we chose to study the emergence and performance of the concept of the 'innovation campus' in the Netherlands, a country with strong traditions of spatial planning and a history of social engineering ambitions. Given the recent emphasis, not only in the Netherlands but also at the EU level, on the stimulation of innovation (cf. the Lisbon agenda), our analysis has also implications for the study of innovation policy, whether it concerns place-based (such as Territorial Innovation Models) or place-neutral approaches (such as ‘smart specialisation’) (Barca et al., 2012, Lagendijk and Varró, forthcoming).

In line with post- structuralist perspectives, we argue that concepts both in general and in planning policies (as conceptual structures) are inherently political. We distinguish between spatial planning concepts and generic planning concepts. Spatial planning concepts directly prescribe spatial form, while generic planning concepts only imply spatial organisation. The Garden City can be seen as a spatial planning concept, while sustainability or innovation can be seen as a generic planning concept.

We take issue with the way the literature has dealt with seemingly vague planning concepts conceptualised as ‘empty signifiers’. The latter are seen as vague concepts, both 
spatial and generic planning concepts, often criticised for that very vagueness, and the associated problems of ideological tainting, over- promise and under- analysis. Drawing on the theorizing on empty signifiers by Laclau, Mouffe and Lacan, as well as on semiotic investigations, and the more planning- focussed work of Gunder and Hillier we argue that these seemingly empty concepts enable the continuous reproduction of the planning enterprise in a radically contingent, complex environment, against the horizon of a barely knowable and producible future. Because of its prominence in planning and governance literature we engage with the concept of empty signifier, the seemingly most promising concept to grasp the functionality of vague concepts in policy settings, but, after discussing the idea, we will replace it with 'open concepts'. ‘Open concepts', we will argue, are less haunted by theoretical over- determination and more tailored to policy analysis. The paradoxical emptiness/fullness of open concepts gives them an array of positive functions in spatial planning.

The study of the open concept of the 'innovation campus' in the Netherlands is based on a discourse analysis of a series of policy documents and consultancy reports (referred to in the article) by the Dutch national government and regional administrations in the Eindhoven city-region. The discourse analysis focuses on the use of concepts in our case and is informed by our conceptual frame. It is supplemented with observations of 7 seminars with consultants, officials and businessmen, and additionally a series of 17 interviews with public officials, architects, consultants, and former board members of Philips.

In the following sections, we briefly reflect on the nature of concepts, then proceed to the analysis of spatial concepts and generic planning concepts, mining the work of Laclau, Lacan, Žižek and others for the functionalities of seemingly empty concepts. Next, we dissect the lineage and functions of the concept of the innovation campus in the context of Dutch planning, and demonstrate how contingent discursive evolutions (to be analysed before policy 
formation) can render a tool intended to stimulate innovation into a tool to maintain the status quo.

\section{Planning concepts in the spatial planning literature.}

Concepts have been an object of reflection in the planning literature. One line of thought can be called 'Dutch-instrumentalist'. The Netherlands have a long planning history and a strong planning culture (van der Cammen and de Klerk, 2003, Faludi and Valk van der, 1994), a planning system with a big impact on the spatial organization of the country. Spatial concepts have played a major role in the shaping of the territory and Dutch planning theorists have consequently been interested in these planning concepts and their performance (Eeten and Roe, 2000, Hagens, 2010, Van Duinen, 2004, Zonneveld, 1991b, Zonneveld, 1991a). The strong focus on spatial concepts in the Dutch planning tradition can be related to the strong belief in the power of planning to organise space and the belief in the importance of plans in visualising space and its future development.

Spatial concepts in this tradition have been analysed as having different functions, varying from visionary and strategic to cognitive and instrumental (Zonneveld, 1991b). Subsequent contributions have framed spatial concepts as ideas which articulate a certain problem and at the same time give a solution for that problem, underpinned by a core idea (e.g. decrease traffic congestion through spatial concentration of urban functions) (Van Duinen, 2004). Recent work by Hagens (2010) focuses on the performance of spatial concepts in bringing together interests of different agents (Hagens, 2010). Yet, while all these functions manifest themselves in concrete planning practices, the overriding ambition is instrumental, that means, organising space (Westerink et al., 2012, Zonneveld, 1991b). The latter is not without its merits. Through their instrumental meaning and role, spatial and generic planning concepts have certainly had a significant impact on spatial organisation, as testified by the 
physical form of the Netherlands. However, such instrumental focus also has serious limitations, especially when one fails to distinguish between cognitive and instrumental functions. As documented by Hagens, such a conflation occurs when the cognitive is harnessed in the service of the instrumental, something which happens all too quickly (Hagens, 2010). Moreover, an instrumental understanding of spatial concepts, and the focus on spatial concepts itself encourages the forgetting of the political and ideological substructures of the concepts (Jensen \& Richardson, 2004). It makes the discussion on alternative understandings of problems and solutions harder, and it assumes steering power where it is only sometimes present (Duineveld and Van Assche, 2011, Scott, 1998).

A second line of reflection on concepts in the planning literature is grounded in broadly post- structuralist perspectives. In this literature (Flyvbjerg, 1998, Gunder and Hillier, 2009, Scott, 1998, Stringer et al., 2006, Van Assche, 2007), the shortcomings of instrumentalist approaches, and the way they are presented as 'objectivist' perspectives have been discussed widely (Healey, 2007, Jensen and Richardson, 2004). In this tradition, the impact of spatial and generic planning concepts has to be studied empirically. Steering power cannot be assumed but has to be observed, and before entering the realm of the prescriptive, alternative understandings have to be brought to the surface. We place ourselves in this line of thought, and intend to demonstrate such modes of observation in the second part of the paper, where we turn back to the Dutch planning context and study the theoretical and practical manifestations of the 'innovation campus' concept. Before doing so, we believe it is useful to take a further step back and scrutinise the concept of concept. This can help in grasping the functions of openness in concepts, which in turn can increase our insight into the role of the open concepts that are so prevalent in spatial planning.

\section{Concepts and planning}


If we want to understand the functions of concepts in planning, it is useful to reflect on the nature of concepts. Understanding space is necessarily a matter of constructing concepts. None of the understandings of space is natural; the concept of landscape is a historical construct, has a genealogy, and even the concept of space itself is the product of historical, cultural and political contingencies (Barnes and Duncan, 1992, Deleuze and Guattari, 1987, Lagendijk et al., 2011, Luhmann, 1995, Massey, 2005, Thrift, 1996). This has been understood by geographers for a long time, and it was a core understanding of French structuralism since the late 1940s. In the post-structuralist period that followed, concepts, spatial concepts and (spatial) planning concepts have been studied from a wide range of angles. In a post- structuralist perspective, concepts are naturally entwining power/ knowledge, whether they are used in deliberate strategies or not (Duineveld and Van Assche, 2011, Feenberg, 1981, Foucault, 2003, Perkins, 1993). Since planning is also a political arena, the strategic use of concepts does deserve special attention (Hillier, 2002).

The understanding of actual spaces and desired/future spaces is articulated through concepts of the same or similar nature, creating a web of resonances and linkages between actual physical spaces and desired/future space (Gunder and Hillier, 2009, Van Assche et al., 2009). Planning future spaces draws on conceptions of actual spaces and communities, as well as their issues, aspirations, assets and tools. If certain communities develop planning systems capable of articulating comprehensive visions for the future, these visions will still be rooted in the interpretation of the world in these communities (Scott, 1998, Van Assche et al., 2009). In addition, spatial planning concepts incorporate a belief that spatial planning is a reliable tool to bring such future closer (Gunder and Hillier, 2007, Healey, 2007), and that a better society has a certain form (Boyer, 1986, Scott, 1998). Generic planning concepts can also articulate aspects of a future spatial organisation that are desirable, without directly outlining a form. 
We can then analyse a community by means of its planning concepts, and we can analyse the impacts of these concepts. In contrast to the instrumental view, concepts do not produce anything automatically or naturally. Implementation is not one step, and certainly not one step that can be taken by a planner (Beunen, 2010, Fischer, 2003, Pressman and Wildavsky, 1984, Scott, 1998). Since implementation requires the involvement of many actors, the impact of a generic planning concept or spatial planning concept requires cooperation of many actors. If the plans and the embedded concepts reflect beliefs already held, implementation will be easier, impact greater (Van Assche et al., 2009). Observation of impact in those cases will often lead to the belief that the concepts one way or another acted themselves, that they incorporated the power of implementation. Assuming that concepts have power gives them power. There is a belief that they reflect reality and a belief that the ones making them have privileged access to reality. This results in a fetishising of concepts (Bowie, 1988, Feenberg, 1981, Perkins, 1993) allowing concepts to appear 'instrumental’. It prompts a mystification of the power of planning, in places where planning works because it is what people want and are used to.

Certain concepts and embedding discourses are widespread in society, and not an object of reflection, while others are rhetorically deployed by certain actors for strategic purposes (Andersen, 2003, Barnes and Duncan, 1992). This distinction opens the door to an understanding of concepts as promotional, as packaging, as persuasive (Throgmorton, 1996), alongside the interpretation of discourses as constituting a symbolic order. One can further distinguish between concepts that pretend to be technical, veiling underlying ideologies and power positions, and concepts that openly represent ideologies or positions of power. More distinctions are certainly possible, and our main point here was to consider these distinctions in the light of different roles and uses of concepts (Eco, 1992). In other words: what is telling about planning and policy evolutions is the use of concepts. Categories of concepts ought to 
be categories of use, as opposed to typologies supposedly representing ontological differences (such as ‘empty signifier’).

\section{Empty signifiers, master signifiers and open concepts}

In the planning literature, drawing on the work of Ernesto Laclau and Chantal Mouffe, notions such as society, sustainability, climate protection, community, planning and innovation have been labelled and explained as ‘empty signifiers’ (cf. Asimakou, 2009, Gunder and Hillier, 2009, Glasze, 2007, Jeffares, 2007, Methmann, 2010). According to Laclau, an empty signifier would be a signifier (the form of a sign) without signified (the represented item). Thus, an empty signifier is produced to signify something which cannot be directly represented (Laclau, 2006). Laclau focused on the category of the empty signifier and he often reduced the functions of emptiness in discourse to the functioning of that category of signs. Although the widespread use of the concept in policy- and planning analysis, it was crafted by Laclau for the analysis of ideological struggles, and therefore not fit for the analysis of policy-concepts, which are commonly within one ideology. Testified by the use of the concept in many studies as a "catchall category for all things undefined, seemingly meaningless and vague” (Jeffares, 2007).

We argue that content without content is logically impossible. Invoking recurring mutual misunderstandings across an antagonistic frontier does not resolve that issue, e.g. what does ‘Orange’ mean in ‘Orange revolution'? Signifiers are neither concepts nor things, and concepts are different from things. Signifiers can neither be full nor empty. Meaning emerges in and as a relation between signifier (sign), signified (concept) and the world as exteriority. Our perspective joins the semiotics of Umberto Eco and Charles Sanders Peirce and Foucault's perspective on discourse, where concepts and discourse create meaning by 
bringing structure in a semantic continuum (Eco, 1979, Eco, 1992, Foucault, 1972).

Alternative structures are possible, and can be competing in ideological struggles. The perspective of parties across an antagonistic frontier might appear meaningless, but that is only because of a perspectival difference.

A more persuasive analysis of the performance of seemingly empty concepts in planning can be found in the work of Gunder and Hillier (2009). Instead of empty signifiers, they draw primarily on the Lacanian notion of 'master signifiers', which are not empty but referring to over- full concepts. In many planning situations, planning concepts such as ‘sustainability’ or ‘innovation’ represent Lacanian master signifiers, referring to concepts that are so open that they can give direction without revealing much detail. Master signifiers can serve as point de capiton in a discourse that threatens to go in too many directions. They can give the impression of pinning down discourse, of agreement on something, before continuing the discussion on futures that can essentially not be known and interests that can essentially not be reconciled. The pretending-to-know embodied by the master signifiers enables the reproduction of discourse (and negotiation) in the face of the abyss of the unknowable and hence the enactment of certain ideological positions (Žižek, 1989, Žižek, 1991, Žižek, 2007). 'Master signifier' can only be understood in a logically consistent and theoretically productive way if it is seen as a category of use, not as a conceptual category that can be simply traced by finding the signifier. Planning concepts, including spatial concepts, can (in a certain use) give the impression of knowing by being vague, the impression of consensus, or the impression of a stepping stone in a collective reasoning. They can function as mastersignifiers in the Lacanian- Žižekian sense. They play this role in the reproduction of discourse in a planning arena, driven by the perceived need to take decisions and keep the planning arena intact. Coming back to the distinction between spatial concepts and generic planning concepts, we can now say that generic planning concepts are likely to invoke master 
signifiers, since the shifting and irreconcilable desires in a community require such concepts to enable continuation of the planning game (Gunder and Hillier, 2009, Luhmann, 1995). Also, we can say that spatial concepts are to be understood against a background of generic planning concepts, including, or drawing on such master signifiers. In other words, the seeming objectivity of spatial concepts, with their direct reference to spatial form, cannot be disconnected from the unknowable represented by the master signifiers. For Lacan, the symbolic order will always reveal cracks; our concepts will always slip off the Real at a certain point, despite the master signifiers that intend to pin down discourse circling around a

world we can never access directly (Lacan and Fink, 2006, Žižek, 1989, Stavrakakis, 1999).

We propose the broader category of 'open concept' to study the variety of functions of seemingly empty concepts in planning and, in fact, governance. 'Empty signifier' we intend to discard for our present purposes, because of the theoretical problems we diagnosed and because of the overly strong association with one political ideology. The functioning as or linkages with master signifiers have to be established in each case, in each contingent evolution of policy and/in community.

In our case study, focusing on a Dutch concept which we label as the 'innovation campus', we look in detail at the relation between spatial and generic planning concepts, the roles of apparent emptiness and the embedding in broader discourses.

\section{The Innovation Campus in the Netherlands}

\section{What is a campus?}

The word campus is derived from Latin, where it indicated an open area or field, most notably the Campus Martius, an open field along the Tiber in Rome (Platner, 1911). A more recent meaning of 'campus' is the grounds of colleges and universities, in a use of the word first encountered in North-America. At Princeton in the late eighteenth century, it referred to the 
green open character of the college (Leith, 1978, Turner, 1987). The word gradually came to signify not only the greenness and remote character of colleges and universities at that time, but the entire property of the university. It also started to refer to the self-contained and selfgoverning community and the distinct architecture expressing the social and educational ideals (Turner, 1987). 'Campus' thus became associated with the original medieval idea of the university: a self- governing learning community, a legal, political and cultural entity partly suspended from the normal regulatory frameworks, to enable learning and discovery (Cobban, 1975). The architectural unity and greenfield isolation were the new, American, elements. This American campus planning tradition, at least in its physical form, was exported to Europe in the second half of the $20^{\text {th }}$ century. In the Netherlands, the first university campus was the University of Twente, followed by the universities of Utrecht and Delft. For the Dutch, 'campus' stood since then for a university campus. This hegemonic meaning was challenged in the first years of the $21^{\text {st }}$ century. New discourses emerged that gave a new meaning to the campus concept, and a series of novel campus developments were initiated in the Netherlands. At least 55 campus developments were under way in 2009 (BCI, 2009). How can we understand this evolution of the 'campus'?

\section{The conception of the campus: High Tech Campus in Eindhoven}

The first non-university development labelled as a 'campus' emerged in Eindhoven, around the former NatLab (research departments) of Philips. In the mid-1990s Philips Electronics CEO Boonstra decided to concentrate research departments previously scattered throughout the Netherlands in Eindhoven. Some years before, members of the executive board visited the Apple Campus in Cupertino, California, part of Silicon Valley, because Apple was for sale at that time. Despite the fact that Philips did not buy Apple, the board was impressed by the 'Apple Campus' and decided to use the term 'campus' for their new research site. Notwithstanding the Apple experience, the 'technology-campus' of Philips was initially an 
ordinary consolidation of research departments. Yet, after a while, it was proclaimed that the new site, south of Eindhoven, could evolve into a 'technology campus', a place of learning and discovery. By the Philips management, this broadening of the campus concept was primarily seen as a compensation for the region of Eindhoven for the relocation of the headquarters to Amsterdam.

The meaning and shape of the technology campus were initially rather unclear. The original plans, presented in October 1997, showed a conglomerate of Philips-departments with a security fence around it. Subsequently, pressure from the municipality prompted a switch in security focus from the perimeters to the individual buildings, allowing for a more accessible campus. The design of the buildings was inspired by the Siemens offices in Munich and other office premises in the Netherlands. The landscape plan was designed with reference to the physical and historical geography of the area, by incorporating features and elements of the existing rural landscapes. In the buildings, glass walls were applied liberally, also for office spaces, and this transparency was thought to encourage collaboration and (self)control.

The ‘Philips High Tech Campus’ opened in 1998 for Philips departments. Because not all buildings were fully occupied, the campus became available for other companies in 2003, after which it was renamed into 'High Tech Campus' (HTC). Despite stated ambitions, the other companies were mainly spin-offs of Philips or supply companies.

The whole planning process was conceived and implemented by Philips, with some input by the city of Eindhoven. The Philips campus can thus be considered a distinctly local adaptation of the campus idea, superficially influenced by Silicon Valley but largely a product of Philips' cost- saving, re-focusing and image- enhancing strategies. Still, in the Netherlands, it was widely perceived as impressive. Many regarded the HTC as a high-quality real estate development, with fine architecture and high-quality landscaping, conveniently located at the 
highway Amsterdam-Eindhoven-Maastricht (A2). Even more, it became a national role model for campus development (cf. Boekholt et al., 2009, BCI, 2009, Tödtling et al., 2011).

\section{Packaging the campus concept}

Six years later, in 2009, the Netherlands had at least 55 campus developments (BCI, 2009). How can we understand this diffusion of the campus concept? The first part of the answer stems from the way the HTC was packaged by the municipal and regional authorities. Building on its history as a corporate 'Philips' town, Eindhoven managed to brand its region as a region of national importance, broadening its basis beyond Philips. Policy-makers at the municipality linked their economic development strategy to the campus development. The City region Eindhoven (Samenwerkingsverband Regio Eindhoven, SRE) developed a similar perspective.

And since the municipality was embedded in policy-networks such as the SRE, Province of Noord-Brabant and Brainport Development Inc. (a public limited company consisting of governmental actors, businesses and knowledge institutes), soon the HTC was embraced by these regional policy-makers. The Eindhoven region, now branded as 'Brainport', transmitted an image of a vivid and innovative technology region, where 'the good life’ was paramount. Brainport received recognition as a national asset by the designation as third national Mainport, after Schiphol airport and Rotterdam harbour (VROM, 2004). A recent policy document by Brainport Development Inc. envisions a “Top Economy, Smart Society”, in which innovation campuses play a crucial role (cf. Tödtling et al., 2011). They form the core of Brainport’s “open innovation eco-system” (Brainport Development, 2011). Campuses now turned from regional to national 'nodal points', as core places where innovation is fostered thanks to intense interaction between universities, businesses and governments. This nationally promoted this particular understanding of the campus concept. 


\section{Campus as a national concept}

Upscaling from the local to the national occurred along two main routes. First, other cities and regions became acquainted with the 'buzz' around Brainport. In addition to regular media channels, such as newspapers, radio, television and internet, important institutional channels were relevant in the spreading of ideas. The name and spatial concept of the HTC travelled, through design competitions, via site visits by policy-makers (e.g. in the collaboration network of 32 urban municipalities, the 'G32'), as well as through seminars for bureaucrats, and via various brands of consultants promoting the new campus idea (and form).

The second route went via the Ministry of Economic Affairs. In 2009, the high number of campus developments, notably their calls for funding, raised the awareness of staff members at the ministry. The question arose what a campus was, how the ministry should respond to these calls and whether it should make campuses part of its innovation policy. Beside internal research, research was commissioned from external consultancy firms to probe the relevance of the campus concept and the scope for policy-making. Boekholt et al. (2009) formulated the following definition based on their research:

"a physical location with high-quality real estate and shared facilities;

with the aim to foster the establishment, growth and acquisition of knowledgeintensive businesses and organizations and their mutual cooperation;

supported by an active policy to facilitate research and development, the transfer of knowledge, people and capital to and between organizations on campus, and a policy to attract knowledge-intensive organizations” (Boekholt et al., 2009: translation by the authors).

Following our conceptual frame, our reading of this first attempt to define a campus is that it 
displayed the width of the concept, allowing for the inclusion of a broad, heterogeneous spectrum of business estates. Accordingly, the report did give a clear answer to what 'it' was. Furthermore, the report stated that the existence of a campus did not automatically lead to improved economic performance at local or regional scales. Nevertheless, the report identified success factors and promoted these factors as criteria for evaluating policy-making. One key conclusion was that government is indispensable, particularly in the early development phase of a campus.

An additional study (BCI, 2009) mapped the campus developments in the Netherlands at the time. It included 55 business estates and other initiatives. The study also added two criteria to the definition of Boekholt et al. (2009):

"the presence of a manifest medium of knowledge relay;

the third criterion of Technopolis should be in terms of an organization that actively stimulates ‘open innovation'.” (BCI, 2009: translation by the authors)

Especially this second report, which was made fully public, triggered a strong response from the media, from members of the Dutch Lower Chamber and drew local policy-makers’ attention. The study used the criteria to assess all 55 business developments and the local organisations behind the winners, the 'campuses of national importance' and 'runners up', proudly promoted their position. Moreover, some of the 'losers' contacted the consultancy $\mathrm{BCI}$ in the hope to be included. Others contested the ranking. A community came into being that promoted a certain understanding of the campus.

Further studies were conducted, now commissioned primarily by provincial authorities and local organizations (BCI, 2010a, BCI, 2010b, VHP et al., 2011). These reports were produced by a wider range of consultancies, thus spreading the campus concept across the 
country. In addition, charismatic 'experts' (mostly working for these consultancies) were invited to all kinds of policy meetings and seminars to shed light on the added value of campus development, its preconditions, what 'it' was, and what municipalities and other organisations could do with campuses. With every meeting, report and seminar, the community responsible for campus development grew and defined itself more clearly, and simultaneously delineated what the campus concept was.

In conclusion, the spatial planning concept of the High Tech Campus in Eindhoven travelled via several institutional networks across the Netherlands, to become the 'innovation campus'. Through these journeys, we can account for the availability of the spatial planning concept as an idea. However, it does not account for the widespread popularity of the concept. Concepts, by and in themselves, do not perform. They have to be embedded in discourse and practice. It is towards this theme that we turn our attention now.

\section{Fertile grounds}

\section{Dutch planning discourse}

To understand the wide adoption of campus development throughout the Netherlands we have to discern the importance of Dutch traditions of spatial planning and its role in economic policy. We will first turn to the Dutch planning discourse, to understand the fertile grounds in which the concept of campus landed. Second, we discuss the role of regional economic policy focusing on specific understandings of innovation. In both cases, we can see how spatial concepts intersect with societal 'master signifiers'.

Spatial planning in the Netherlands has been traditionally used to tackle a wide range of societal problems, spatial as well as sectoral. The spatial planning concept of 'bundled deconcentration' (gebundelde deconcentratie) launched in 1966 is a good example of this stance towards planning (VRO, 1966).Through the implementation of 'bundled 
deconcentration', policy-makers believed that social problems which existed in large metropolises such as London or Paris could be avoided in the Netherlands, through concentrating urban growth throughout the entire country in so-called overspill towns (groeikernen). Another example is the design of the Noordoostpolder (1936-1942) which was planned according to the Central Place Theory of Walter Christaller, together with ideas on social engineering (Simon, 2005). Contemporary policies still have the underlying assumption of socio- economic problem-solving through spatial planning. Despite the alleged shift from 'government to governance', and moves away from the centrally managed 'welfare state', Dutch administration is still heavily engaged in the shaping of space. Indeed, Dutch spatial planning is still grounded in two basic assumptions: (1) planning policies can actually determine spatial form over the long term and in large areas, and (2) spatial form enhances socio- economic performance.

In recent decades, two major shifts have taken place, yielding a more entrepreneurial (or businesslike) planning style. First, planning has moved from a role of coordinating land use to active investments, notably in what is denoted as 'area development'. Second, the goals (and justification) of spatial planning have moved from the social (originally the social'hygienic') to the economic. The latter is particularly noticeable in the latest National Spatial Strategy of 2004. This policy document displays a clear 'economization of spatial policy' (Lagendijk and Boekema, 2009, VROM, 2004, Zonneveld and Verwest, 2005), infused by two supporting discourses around the planning concepts ‘competitiveness' and 'innovation', which will now be discussed in more detail.

\section{Regional-economic discourse}

The turn to a more economic focus in spatial planning has been influenced, first of all, by changes in the discourse on regional-economic policy in the 1990s. Prompted by various white papers issued by the Ministry of Economic Affairs (EZ, 1995, EZ, 1999, EZ and BCI, 
1997, EZ and Kolpron Consultants, 1994a, EZ and Kolpron Consultants, 1994b), the government started to stimulate the economic potential of regions, and started to improve the accessibility and quality of industrial and business estates. In the 1990s the most important means of supporting the industry were in accordance with the ideas of Michael Porter, who promoted competitiveness of regions through innovation and clusters of businesses (Raspe and van Oort, 2007). Initially, there was little attention for qualities that could be influenced through spatial planning, with the exception of physical accessibility, but this changed dramatically in the two decades that followed.

A crucial turn occurred in 1994, when in a preliminary study for the memorandum 'Space for Regions’ (Nota Ruimte voor regio’s), the directorate of the Ministry of Economic Affairs claimed a 'deficiency' in Dutch spatial policies: there was no policy which addressed the space needed for 'the economy' (EZ and Kolpron Consultants, 1994b). This was the start of a continuous explicit formulation of spatial issues in favour of the economy, resulting in a ‘spatialization' of regional economic policy (together with a reorientation of planning towards economic development). Also the designation of the Mainports and Brainport as both a spatial and economic process is part of this trend in policy

In terms of concrete policy-making, the Ministry of Economic Affairs contributed to this shift through the programme 'Peaks in the Delta' (2007-2011). The programme introduced an area specific innovation policy, in which a limited number of innovation regions were selected as internationally competitive 'hot spots'. Two core criteria were set for the 'Peaks': a high level of organization around the theme of innovation and the presence of high-quality knowledge infrastructure. Initially, four regions were able to meet the demands: South-East Brabant ('Brainport' Eindhoven), East-Netherlands, the North- and South-Wing of the Randstad. Bottlenecks were to be removed and new policy-instruments had to be tailormade (EZ, 2004). 
Another influential discourse is the one around the concept of innovation, which developed in two waves. A first wave can be discerned in the recession of the 1970s and 80s, which was a response to an aged industrial sector in the Netherlands. Two white papers, the national ‘Innovation Memorandum’ of 1979 and a report by the Scientific Council in 1980, argued that technological innovation could offer a shift towards a more high-quality industry (OCW, 1979, WRR, 1980), supporting the idea that industrial policy should move from 'backing losers' towards 'picking winners' (Velzing, 2011). A second wave was apparent in the 1990s and early 2000s, which was not a response to a real recession, but to national and international reports and benchmarks (e.g. The Global Competitiveness Report). Following these reports, the Dutch competitiveness in the 'knowledge economy’ was supposedly endangered. References were made to 'rising stars', such as India, China etc., and the fact that the Netherlands was “losing momentum” (Innovatieplatform, 2004). Thus, a sense of urgency was created and action was called for.

The discourse on innovation was nurtured and broadcast by a specific institution, the Innovation Platform (Innovatieplatform), chaired by the then Prime Minister Jan-Peter Balkenende (2003-2010). The Innovation Platform made many proposals, including a proposal to enforce so-called Key areas (Sleutelgebieden). Instead of 'picking winners' in a top-down manner, the platform aspired a bottom-up approach, by asking stakeholders to mention powerful combinations of knowledge and businesses and to identify scope for improvement. After this call, a selection was made and ten key themes were identified, such as 'Flowers and Food', 'High-tech Systems and Materials', 'Chemistry’ and 'Sustainable Energy’ (Innovatieplatform et al., 2004). Although these key theme were not necessarily geographical, certain geographical 'hot spots’ (in Dutch: 'hotspots’) within these Key areas were distinguished. In hindsight, despite the ‘bottom-up’ aspiration, the Platform’s approach 
was still dominated by top-down imposed ideas regarding areas in which innovation should be encouraged (Innovatieplatform et al., 2004). However, the contribution of the Key area approach to ‘innovation’ remained rather unclear.

In a second round, the Innovation Platform continued and advanced the Key areas approach, as detailed in the vision document 'Netherlands 2020' (Innovatieplatform, 2010). 'Netherlands 2020' pleaded for a modern industrial policy, in which the Key areas policy was made to mean an allocation of at least $50 \%$ of the innovation budget in these areas. Importantly, the document also advocated the development of five or six 'innovation campuses', such as the HTC, as geographical 'hot spots'. Regional governments, businesses, knowledge institutions and investors were supposed to invest hundreds of millions of euros for each innovation campus, thereby pinning down the discourse. Innovation was to be fostered by collaborating businesses and knowledge institutions following an 'open innovation' model (Innovatieplatform, 2010). With the spatial concept of the innovation campus, the conceptually and spatially undetermined concept 'innovation’ could get a little more foothold.

After the platform was abolished in 2010, what remained was not so much a widely shared innovation discourse or practice, but innovation as a master signifier, that, in its embodiment of innovation campus, and alongside concepts of clustering and competitiveness, injected new ideas of 'area development' in spatial policy, thus contributing to a further spatialization of economic policy and a deepening of the economic orientation of spatial planning.

In conclusion, the Dutch fertile grounds for the reception of the innovation campus were discourses on spatial planning, on regional economic development and on innovation. Albeit different in their genealogy, these discourses display an underlying ideology of social engineering. This ideology structured much of the interpretation of spatial and generic 
planning concepts introduced from elsewhere, their translation and implementation.

\section{Functions of open concepts}

As illustrated in our case, copying and travelling of concepts means emptying, diluting and transforming of concepts (cf. Bal, 2002). Although it was often acknowledged that the American success (i.e. Silicon Valley) was impossible to copy, policy-makers implicitly structured their interpretation of and expectations for the new style campus along the lines of their interpretation of Silicon Valley. Institutional specificities were overlooked (or wilfully ignored), such as the cooperation model in the Netherlands (universities, businesses, governments), against the dominant role of venture capitalist in Silicon Valley (Ferrary and Granovetter, 2009). The travels of the campus concept demonstrate the different meanings of the concept in America, in Eindhoven, in Brainport and nationally in the Netherlands. The spatial concept was used differently in each context, which included an emptying of the concept and attributing different meaning to it. Thus, the functions of open concepts during migration hinge on mutation and hybridization.

Because meaning is constructed by subjects retroactively (Žižek, 1989), many officials were able to stage their favourite development as a campus, thereby temporarily stopping the sliding of meaning. Their project became a campus for them, and became associated with new expectations. Often, campus developments were presented as the solution to local policy problems: the possible retreat of multinationals (e.g. DSM in Geleen, MSD in Oss, Solvay in Weesp), the restructuring of obsolete industrial areas (e.g. Nijmegen, Geleen), demographic decline (e.g. The Province of Limburg), the lack of economic growth or the invisibility of cluster policy. In all cases, it was campus development which had to solve policy problems, which, of course, included certain fantasmatic elements. Because the notion of campus was 'opened', all kinds of associations could be made with it. Moreover, although these 
conceptual linkages were novel, they did not really change the discursive world of policymakers. Instead, they reinforced old ideas and practices emerging from old discourses, such as the Dutch tradition of spatial planning and social engineering.

The use of open concepts helps in obscuring uncertainties and risks in social and political life. Glossing over these uncertainties enables advancements on issues and a continuation of social and political life. Without open concepts that veil the impossibility to know the future, there will be no seemingly firm ground to stand on (Peirce, 1877). Because of this silent and generalized performativity, certain experts or politicians can consciously and tactically act as if things can be predicted. And, most crucially, many in our current society want those people to know, want to believe that things can be known (cf. Žižek, 1997).

Spatial planning concepts (such as the innovation campus) and generic planning concepts (such as innovation) work. They perform. They do not have a fixed essence or core, rather their meaning is generated through relations. Any social practice, and especially one looking at many interests and an unknowable future -such as spatial planning- will need at least a number of concepts that can be reinterpreted in a flexible manner. This flexibility makes them work. Multiple meanings can be attributed to them which allows them to be linked to many discourses at the same time. In some cases, this will spur innovation, while in others, such as the case studied, new concepts, even when addressing innovation, can just as well keep existing discursive configurations in place.

\section{Conclusion}

Understanding the functions of spatial concepts necessarily involves understanding the nature of concepts. Concepts structure the complex world we live in, and thus create the world as we know it. What concepts ‘are’ and ‘do’ remains a major philosophical puzzle, resonating in the debate on the role of concepts in the planning literature. This literature has generally 
highlighted the 'performative' nature of planning concepts. By entwining power/knowledge, concepts come across as 'natural', as well as infusing investments in them by planning actors. We should always acknowledge that they are as contingent and historical as other concepts. The question then is why certain spatial or generic planning concepts work where others fail, or in other words, which functions of concepts can be distinguished?

In this paper we have discussed the evolution of planning concepts in light of the broader discussion on concepts and policies. It has been claimed by others that concepts 'perform' because of their emergence as 'empty signifier'. Here, we argue that to understand the role of core concepts (such as sustainability or accessibility) the characterisation 'empty' confuses. More helpful is the notion of 'open concept', as a further specification of 'master signifiers` (in Lacanian sense), that can be linked differently in distinct empirical settings and discursive evolutions. This insight can only be grasped productively when open concepts and master signifiers are seen as categories of use in discursive configurations. Usages can be of different kinds, some are more naturalized in society at large, whereas others can be deployed more strategically by actors.

In Lacanian terms, spatial concepts serve as a point de capiton, and pin down knotty discourses which, taken individually, tend to go in diverse directions, such as discourses on spatial-economic development and spatial planning. The pinning down, the precision of it, has to be partly fictitious to remain functional. The appearance of precision has to be functional openness. Spatial concepts thus have to function as open concepts to serve as a middle ground, as a crystallization point of various discourses and an enabler of their reproduction. In this paper, we demonstrated this 'middle ground' role by studying the concept of campus, and its discursive migration including mutation and hybridization. In the Dutch case we saw a travel of campus ideas from Silicon Valley, via the Apple campus, with its distinct translation and practical interpretation in Eindhoven, and then spreading across the country, merging 
with other interpretations of high-tech companies, real estate developers, and others. This subsequently led to distinct localized models, all unique in their own right, but all carrying traces of former discourses and models from elsewhere.

This conceptual flexibility also enables the continuation of the planning game. Actors are broadly able to continue their planning practices through these open concepts, The result is the continuation of the whole game, without changing too much of the rules of the game, but with a clear signification of our desires and actions. While any attempt to signify the future, or any attempt to plan the future is destined to be imperfect, they play a vital symbolic role. Open concepts mediate the uncertainty of the future and adjust to the continuously produced present. If we would fully submit ourselves to the idea that the future is unknowable and that it is not possible to plan, planning would be virtually impossible. The added appearance of precision by spatiality in the case of spatial planning concepts adds to the repertoire of mechanisms veiling uncertainty and contingency.

Open concepts enable the capturing of desires of society in the face of an uncertain future. They allow projections of a good future, a means to get to our desires, in the case of the innovation campus: to the 'good life' in which societal problems are 'solved' and everybody lives in a wealthy, fair society fuelled by ‘high tech’ Silicon Valley-like spaces. As such, they function as imaginaries, strongly underpinned by underlying ideologies. Analysis of such concepts allow insight in these ideologies. Thus, reflecting upon the functions of open concepts, the underlying ideological assumptions can be uncovered, which allows the opening of a space for discussion concerning these ideological assumptions. 'On the ground', on the other hand, a concept like 'campus' shows how meaning is temporally fixed, how space is given form, and how this form can be planned, organised and designed by government, fitting in the Dutch planning tradition. 


\section{Acknowledgements}

The authors would like to thank Daan Boezeman, Joren Jacobs and the anonymous reviewers for their valuable comments and suggestions to improve the quality of the paper. The research for this paper is part of a $\mathrm{PhD}$ research financed by the NICIS institute within the research programme Knowledge for powerful cities.

\section{References}

ANDERSEN, N. Å. 2003. Discursive analytical strategies: understanding Foucault, Koselleck, Laclau, Luhmann, Bristol, The Policy Press.

ASIMAKOU, T. 2009. Innovation, Knowledge and Power in Organizations, Abingdon, Oxon; New York, Routledge.

BAL, M. 2002. Travelling Concepts in the Humanities: A Rough Guide, Toronto, University of Toronto Press.

BARCA, F., MCCANN, P. \& RODRÍGUEZ-POSE, A. 2012. THE CASE FOR REGIONAL DEVELOPMENT INTERVENTION: PLACE-BASED VERSUS PLACENEUTRAL APPROACHES. Journal of Regional Science, 52, 134-152.

BARNES, T. J. \& DUNCAN, J. S. 1992. Writing worlds: discourse, text, and metaphor in the representation of landscape, London, Routledge.

BCI 2009. Fysieke investeringsopgaven voor campussen van nationaal belang. Nijmegen: BCI.

BCI 2010a. Ontwikkeling van (clusters en) campussen in Gelderland. Nijmegen:

Commissioned by the Province of Gelderland.

BCI 2010b. Op weg naar een Brainport Campussenstragie. In: SRE SAMENWERKINGSVERBAND EINDHOVEN (ed.). Eindhoven.

BEUNEN, R. 2010. The Governance of Nature. How nature conservation ambitions have been dashed in planning practices. PhD., Wageningen University.

BOEKHOLT, P., NAGLE, M. \& ZUIJDAM, F. 2009. Campusvorming. Studie naar de meerwaarde van campussen en de rol van de overheid met betrekking tot campusvorming. Amsterdam: Technopolis. 
BOWIE, M. 1988. Freud, Proust and Lacan: theory as fiction, Cambridge, Cambridge University Press.

BOYER, M. C. 1986. Dreaming the rational city: the myth of American city planning, Cambridge, Massachusetts, MIT Press.

BRAINPORT DEVELOPMENT 2011. Brainport 2020. Top economy, smart society. Visie, strategie en uitvoering [Vision, strategy and implementation]. Eindhoven: Brainport Development NV.

COBBAN, A. B. 1975. The medieval universities: their development and organization, London, Methuen.

DELEUZE, G. \& GUATTARI, F. 1987. A thousand plateaus: capitalism and schizophrenia, London, Continuum.

DUINEVELD, M. \& VAN ASSCHE, K. 2011. The Power of Tulips: Constructing Nature and Heritage in a Contested Landscape. Journal of Environmental Policy \& Planning, 13, 79-98.

ECO, U. 1979. A theory of semiotics, Bloomington, Indiana University Press.

ECO, U. 1992. La production des signes., Paris, Livre de Poche.

EETEN, M. V. \& ROE, E. 2000. When Fiction Conveys Truth and Authority. Journal of the American Planning Association, 66, 58-67.

EZ 1995. Ruimte voor regio's. Het ruimtelijk-economisch beleid tot 2000. Den Haag: SDU uitgeverij.

EZ 1999. Nota Ruimtelijk Economisch Beleid. Den Haag: Ministerie van Economische Zaken.

EZ 2004. Pieken in de Delta: gebiedsgerichte economische perspectieven. In: BELEID, R. E. (ed.). Den Haag: Ministerie van Economische Zaken, Directie Ruimtelijk Economisch Beleid.

EZ \& BCI 1997. Ruimte voor Economische Dynamiek. Den Haag: Ministerie van Economische Zaken.

EZ \& KOLPRON CONSULTANTS 1994a. Ruimte voor Economische Activiteit. Concurrerende en complementaire ruimteclaims in rijksnota's. Den Haag: DirectoraatGeneraal voor Economische Structuur.

EZ \& KOLPRON CONSULTANTS 1994b. Ruimte voor Economische Activiteit. Verkennende analyse van de ruimtelijke ontwikkelingsmogelijkheden voor economische activiteiten. Den Haag: Directoraat-Generaal voor Economische Structuur.

FALUDI, A. \& VALK VAN DER, A. 1994. Rule and order: Dutch planning doctrine in the twentieth century, Dordrecht, Kluwer Academic Publishers. 
FEENBERG, A. 1981. Lukács, Marx, and the sources of critical theory, Lanham, Maryland, Rowman and Littlefield.

FERRARY, M. \& GRANOVETTER, M. 2009. The role of venture capital firms in Silicon Valley's complex innovation network. Economy and Society, 38, 326-359.

FISCHER, F. 2003. Reframing public policy: discursive politics and deliberative practices, Oxford, Oxford University Press.

FLYVBJERG, B. 1998. Rationality and Power. Democracy in Practice, Chicago \& London, The University of Chicago Press.

FOUCAULT, M. 1972. Archaeology of Knowledge, London, New York, Routledge.

FOUCAULT, M. 2003. Society must be defended: lectures at the Collège de France, 197576, New York, Picador.

GLASZE, G. 2007. The Discursive Constitution of a World-Spanning Region and the Role of Empty Signifiers: The Case of Francophonia Geopolitics, 12, pp. 656-679(24).

GUNDER, M. \& HILLIER, J. 2007. Planning as urban therapeutic. Environment and Planning A, 39, 467-486.

GUNDER, M. \& HILLIER, J. 2009. Planning in ten words or less: a Lacanian entanglement with spatial planning, Farnham, Ashgate.

HAGENS, J. E. 2010. The performance of landscape concepts in spatial planning : branding, bonding and bringing about. $\mathrm{PhD}$, Wageningen University.

HEALEY, P. 2007. Urban complexity and spatial strategies: towards a relational planning for our times, Milton Park, Abingdon, Routledge.

HILLIER, J. 2002. Shadows of power: an allegory of prudence in land-use planning, Milton Park, Abingdon, Routledge.

INNOVATIEPLATFORM 2004. Werken aan innovatie. De start van het innovatieplatform. Den Haag: Innovatieplatform.

INNOVATIEPLATFORM 2010. Nederland 2020: terug in de top 5. De economische agenda: Innovatief, Internationaal, Involverend. Den Haag: Innovatieplatform.

INNOVATIEPLATFORM, TILBURG, R. V. \& BEKKERS, F. 2004. Voorstellen Sleutelgebieden-aanpak. Ambitie, excellentie en actie. Van dijkgraaf tot art director: voorstellen tot actie van het Innovatieplatform. Den Haag: Innovatieplatform.

JEFFARES, S. R. 2007. Why Public Policy Ideas Catch on: Empty Signifiers and Flourishing Neighbourhoods. PhD, University of Birmingham.

JENSEN, O. B. \& RICHARDSON, T. 2004. Making European Space. Mobility, power and territorial identity, London and New York, Routledge.

LACAN, J. \& FINK, B. 2006. Écrits: The First Complete Edition in English, London \& New 
York, W. W. Norton.

LACLAU, E. 2006. Ideology and post-Marxism. Journal of Political Ideologies, 11, 103-114.

LAGENDIJK, A. \& BOEKEMA, F. 2009. The Territoriality of Spatial-Economic

Governance in Historical Perspective: The Case of The Netherlands. In: ARTS, B., LAGENDIJK, A. \& VAN HOUTUM, H. J. (eds.) The Disoriented State: Shifts in Governmentality, Territoriality and Governance. Dordrecht: Springer Netherlands.

LAGENDIJK, A., PIJPERS, R., ENT, G., HENDRIKX, R., VAN LANEN, B. \& MAUSSART, L. 2011. Multiple Worlds in a Single Street: Ethnic Entrepreneurship and the Construction of a Global Sense of Place. Space and Polity, 15, 163-181.

LAGENDIJK, A. \& VARRÓ, K. forthcoming. European innovation policies from RIS to smart specialisation - a policy assemblage perspective. In: CARAYANNIS, E. \& KORRES, G. (eds.) The Innovation Union Status and the Road Ahead: A SocioEconomic Integration Perspective of the European Union. Cheltenham (UK); Camberley (UK); Northampton (USA): Edward Elgar Publishing

LEITH, A. 1978. A Princeton Companion, Princeton, New Jersey / Guildford, Surrey, Princeton University Press.

LUHMANN, N. 1995. Social systems, Palo Alto, Stanford University Press.

MASSEY, D. B. 2005. For space, London, SAGE.

METHMANN, C. P. 2010. 'Climate Protection’ as Empty Signifier: A Discourse Theoretical Perspective on Climate Mainstreaming in World Politics. Millennium - Journal of International Studies, 39, 345-372.

OCW 1979. Innovatie. Het overheidsbeleid inzake technologische vernieuwing in de Nederlandse samenleving, Den Haag, OCW.

PEIRCE, C. S. 1877. The Fixation of Belief. Popular Science Monthly, 1-15.

PERKINS, S. 1993. Marxism and the proletariat: a Lukácsian perspective, London, Pluto Press.

PLATNER, S. B. 1911. The Topography and Monuments of Ancient Rome, Boston, Allyn and Bacon.

PRESSMAN, J. L. \& WILDAVSKY, A. B. 1984. Implementation: how great expectations in Washington are dashed in Oakland : or, why it's amazing that federal programs work at all, this being a saga of the Economic Development Administration as told by two sympathetic observers who seek to build morals on a foundation of ruined hopes, Berkeley, University of California Press.

RASPE, O. \& VAN OORT, F. 2007. Ruimtelijkeconomisch beleid in de kenniseconomie. In: PLANBUREAU), P. V. D. L. R. (ed.). Den Haag: Ruimtelijk Planbureau.

SCOTT, J. C. 1998. Seeing like a state: how certain schemes to improve the human condition have failed, New Haven and London, Yale University Press. 
SIMON, C. J. M. 2005. Ruimte voor identiteit. De productie en reproductie van streekidentiteiten in Nederland. PhD., Rijksuniversiteit Groningen.

STAVRAKAKIS, Y. 1999. Lacan and the political, Abingdon and New York, Routledge.

STRINGER, L., DOUGILL, A., FRASER, E., HUBACEK, K., PRELL, C. \& REED, M. 2006. Unpacking” Participation” in the Adaptive Management of Social-ecological Systems: a Critical Review. Ecology and Society, 11, 22.

THRIFT, N. J. 1996. Spatial formations, London, Sage.

THROGMORTON, J. A. 1996. Planning as persuasive storytelling: the rhetorical construction of Chicago's electric future, University of Chicago Press.

TÖDTLING, F., VAN REINE, P. P. \& DÖRHÖFER, S. 2011. Open Innovation and Regional Culture-Findings from Different Industrial and Regional Settings. European Planning Studies, 19, 1885-1907.

TURNER, P. V. 1987. Campus. An American Planning Tradition, Cambridge, Massachusetts; London, England, The MIT Press.

VAN ASSCHE, K., DEVLIEGER, P., TEAMPAU, P. \& VERSCHRAEGEN, G. 2009. Forgetting and remembering in the margins: Constructing past and future in the Romanian Danube Delta. Memory Studies, 2, 211-234.

VAN ASSCHE, K. A. M. 2007. Planning as/ and/ in context: Towards a new analysis of context in interactive planning. Middle Eastern Technical University Journal FA, 24, 105-117.

VAN DER CAMMEN, H. \& DE KLERK, L. A. 2003. Ruimtelijke ordening: van grachtengordel tot Vinex-wijk, Houten, Antwerpen, Het Spectrum.

VAN DUINEN, L. B. J. 2004. Planning imagery: the emergence and development of new planning concepts in Dutch national spatial policy Amsterdam, University of Amsterdam (PhD thesis).

VELZING, E.-J. 2011. Economische Zaken in de jaren '80 van de 20e eeuw. Een gedwongen overstap naar technologiebeleid. In: SIC (ed.) SIC Nieuwsbrief mei 2011. Hoofddorp Stichting voor Industriebeleid en Communicatie.

VHP, METRUM \& ROYAL HASKONING 2011. High Tech Automotive Campus. Masterplan. In: GEMEENTE HELMOND \& VASTGOEDONTWIKKELING, H. (eds.). Helmond: Gemeente Helmond.

VRO 1966. Tweede nota over de ruimtelijke ordening in Nederland. Den Haag: Staatsuitgeverij.

VROM 2004. Nota Ruimte. Ruimte voor ontwikkeling. Den Haag: VROM.

WESTERINK, J., LAGENDIJK, A., DÜHR, S., JAGT, P. V. D. \& KEMPENAAR, A. 2012. Contested spaces? The use of place concepts to communicate visions for peri-urban areas. European Planning Studies, 1-21. 
WRR 1980. Plaats en toekomst van de Nederlandse industrie. Den Haag: Staatsuitgeverij.

ŽIŽEK, S. 1989. The Sublime Object of Ideology, London and New York, Verso.

ŽIŽEK, S. 1991. For they know not what they do: enjoyment as a political factor, London and New York, Verso.

ŽIŽEK, S. 1997. The Plague of Fantasies, London and Brooklyn NY, Verso.

ŽIŽEK, S. 2007. How to read Lacan, London \& New York, W.W. Norton \& Company.

ZONNEVELD, W. 1991a. Conceptvorming in de ruimtelijke planning: encyclopedie van planconcepten, Amsterdam, Universiteit van Amsterdam, Planologisch en Demografisch Instituut.

ZONNEVELD, W. 1991b. Conceptvorming in de ruimtelijke planning: patronen en processen. $\mathrm{PhD}$. PhD, Universiteit van Amsterdam.

ZONNEVELD, W. \& VERWEST, F. 2005. Tussen droom en retoriek. De conceptualisering van ruimte in de Nederlandse planning, Rotterdam \& Den Haag, NAi Uitgevers \& Ruimtelijk Planbureau. 